\section{Dopamine and antipsychotic drug action revisited}

\author{
H. M. JONES and L. S. PILOWSKY
}

The key event in the initiation of pharmacological responses is the formation of a complex between the ligand (or drug or molecule) and its site of action (Taylor \& Insel, 1990). Competitive binding experiments ascertain how specific the interaction is between a ligand and its binding site by examining the ability of various compounds to compete with a radiolabelled reference probe for the site. The more potently a drug binds to the receptor, the more effective it is at competing for labelled sites. The greater the potency a drug has for the receptor, the lower the concentration required before all available receptor sites are occupied or blocked. This affinity (termed $K_{\mathrm{d}}$ or $K_{\mathrm{i}}$ ) for the receptor is quantified in test-tube experiments and is a function of the rate of drug association and dissociation from the receptor. It is empirically measured as the concentration of drug required to block half the total receptor population. High-affinity drugs have low $K_{\mathrm{d}}$ values. These drugs are better at 'occupying' receptors. In living animals, including humans, receptor occupancy by drugs is also determined by the rate of association and dissociation of the drug from the receptors, the concentration of drug at the receptor and the concentration of endogenous neurotransmitter at the receptor (Strange, 2001). Rehearsing these dry pharmacological concepts is important to our understanding of antipsychotic drug action, in particular how dopamine is the 'comeback kid' for hypotheses of antipsychotic drug action, a lead candidate for antipsychotic drug discovery and relevant to the modern clinical management of schizophrenia. Here we shall discuss the dopamine hypothesis of drug action, review studies that have refined understanding of its relevance, and attempt to synthesise the current view with respect to clinical management.

\section{DOPAMINERGIC PATHWAYS AND RECEPTOR PHYSIOLOGY}

Dopamine is one of the principal modulatory neurotransmitters in the brain. Dopamine systems arise from two primary midbrain clusters, the ventral tegmental area (A10) and the substantia nigra (A9), which have discrete projections to mesolimbic, mesocortical and striatal regions of the brain. A separate tuberoinfundibular pathway runs from hypothalamic neurons to the pituitary gland. The dopamine receptor family separates into two major subtypes: $D_{1}$-like $\left(D_{1}\right.$ and $\left.D_{5}\right)$ and $D_{2}$-like $\left(D_{2}, D_{3}, D_{4}\right)$. Variants of the dopamine receptors exist with different DNA and amino acid sequences. Receptor cloning has identified two isoforms of the $\mathrm{D}_{2}$ receptor $\left(\mathrm{D}_{2 \text { short }}\right.$ and $\left.\mathrm{D}_{2 \text { long }}\right)$, which are differentially localised in the brain. The neurochemical anatomy of dopamine differs in cortical and striatal regions, and it now appears that dopamine concentration, receptor regulation and $\mathrm{D}_{2}$-like receptor subtype density vary greatly between striatal and extrastriatal regions (Lidow et al, 1998; Strange, 2001). Antipsychotic drugs are thought to achieve their main effects (both beneficial and unwanted) by acting on $\mathrm{D}_{2}$ receptors.

\section{DOPAMINE RECEPTORS AND ANTIPSYCHOTIC DRUG ACTION}

\section{The $\mathrm{D}_{2}$ receptor blockade hypothesis}

Without exception, effective antipsychotic drugs have at least some degree of antagonism of the dopamine $\mathrm{D}_{2}$ receptors. The observation that antipsychotic drug affinity for the $D_{2}$ receptor and the average daily dose required to control symptoms were directly correlated (Peroutka \& Snyder, 1980) led to confirmation that it was a major site of action of antipsychotic drugs
(Creese et al, 1976; Seeman et al, 1976; Johnstone et al, 1978). These findings rationalised clinical observation and practice at the time. Efforts to treat partially or poorly responsive patients revolved around 'mega-dose' antipsychotic therapy, although many contemporaneous papers questioned the usefulness of this approach (Baldessarini et al, 1984; Van Putten \& Marder, 1986). More $\mathrm{D}_{2}$ receptor blockade was better, the theory went, and concomitant movement disorder (secondary to striatal $\mathrm{D}_{2}$ receptor blockade) and hyperprolactinaemia (secondary to pituitary $\mathrm{D}_{2}$ blockade) were an inevitable, if unfortunate, corollary of treatment.

\section{Re-evaluation of the dopamine hypothesis of antipsychotic drug action}

In the 1980s and 1990s the simple understanding that dopamine $\mathrm{D}_{2}$ receptor blockade was linearly related to clinical response was reversed (as is so often the case in schizophrenia research) by powerful new research tools, which forced the re-evaluation of the role of $\mathrm{D}_{2}$ receptors in antipsychotic drug action. These included receptor imaging in vivo with positron and single photon emission tomography (PET and SPET). One PET study showed that up to 12 different typical antipsychotic drugs had $65-85 \%$ occupancy at $\mathrm{D}_{2}$ receptors in living patients (Farde et al, 1989). Subsequent studies revealed that the degree of $\mathrm{D}_{2}$ receptor occupancy was directly correlated with the dose (or plasma level) of traditional antipsychotic drugs; but did $D_{2}$ receptor occupancy also correlate with clinical benefit?

Chinks in the 'dopamine hypothesis' armour appeared with the clear demonstration that some patients taking therapeutic doses of typical antipsychotic drugs not only failed to benefit from the treatment, but also had levels of central $\mathrm{D}_{2}$ receptor blockade in excess of $90 \%$ (Wolkin et al, 1989; Pilowsky et al, 1993). This finding obviated pharmacokinetic explanations that poor clinical effect was the result of low brain penetration or increased wash-out of typical antipsychotic drugs in treatment-resistant individuals. Indeed, some patients who responded well to treatment showed remarkably low levels of $\mathrm{D}_{2}$ receptor blockade (Pilowsky et al, 1993). These data contributed greatly to the consensus that high-dosage antipsychotic treatment was, 
in the main, unhelpful in the treatment of poorly responsive schizophrenia (Thompson, 1994). Finally, clozapine, a therapeutically superior antipsychotic drug without extrapyramidal side-effects (and modest affinity for $\mathrm{D}_{2}$ receptors in vitro) had consistently low levels of $\mathrm{D}_{2}$ receptor blockade (ranging from $20 \%$ to $60 \%$ ) in association with excellent clinical response, even in patients previously poorly responsive to standard or high-dosage typical antipsychotic drug therapy (Pilowsky et al, 1992).

This evidence prompted a careful reinterpretation of the importance of $\mathrm{D}_{2}$ receptor blockade to therapeutic efficacy. Other receptor systems were probed as potential sites of antipsychotic drug action, and a call was made to abandon preconceived ideas of particular neurochemical profiles determining atypical drug activity until potential sites for drug discovery were better understood (Kerwin, 1994). Simple behavioural or clinical definitions of atypicality (low or no extrapyramidal symptoms or hyperprolactinaemia at therapeutically relevant doses) would preserve an open field for novel therapeutic targets. Most notable of these was the 5-hydroxytryptamine type $2\left(5-\mathrm{HT}_{2}\right)$ receptor subclass. Meltzer et al (1989) proposed, on the basis of drug affinity data, that the ratio of $5-\mathrm{HT}_{2 \mathrm{~A}}$ to $\mathrm{D}_{2}$ receptor affinities was the major determinant of a drug's likelihood to behave as an atypical antipsychotic. Studies using PET and SPET found that many atypical antipsychotic drugs, including clozapine, olanzapine, risperidone and quetiapine, shared a strikingly high degree of $5-\mathrm{HT}_{2 \mathrm{~A}}$ receptor occupancy (>90\%) over their entire dose range (Nordstrom et al, 1993a; Nyberg et al, 1993; Travis et al, 1998; Kapur et al, 1999; Jones et al, 2001). This is unsurprising given that olanzapine, risperidone and quetiapine were developed on the basis of their high $5-\mathrm{HT}_{2 \mathrm{~A}}: \mathrm{D}_{2}$ receptor affinity profiles. It appears from the results of further studies (particularly the failure of pure $5-\mathrm{HT}_{2 \mathrm{~A}}$ antagonists to show striking therapeutic effects) that 5 $\mathrm{HT}_{2 \mathrm{~A}}$ receptor occupancy alone is unlikely to be sufficient to determine clinical efficacy for antipsychotic drugs (Kapur et al, 1999).

\section{The central primacy of dopamine to antipsychotic action}

The notion that $\mathrm{D}_{2}$ receptor occupancy was central to therapeutic response never really went away. Compounds that lack even modest activity at these sites are therapeutically inactive. Nordstrom et al (1993b) and later Kapur et al (2000a) showed that symptom reduction and sideeffect induction could be fitted to a threshold model of striatal $\mathrm{D}_{2}$ receptor occupancy (at least in acutely relapsed patients and excluding excellent responders and treatmentresistant cases). In one study of 22 patients (5 women and 17 men) with first-episode schizophrenia, Kapur et al (2000a) demonstrated that striatal $\mathrm{D}_{2}$ receptor occupancy values exceeding approximately $65 \%$ predicted clinical benefit, values exceeding $72 \%$ predicted hyperprolactinaemia, and values exceeding $78 \%$ predicted motor side-effects. For the clinician, maintaining patients within a therapeutic window of $7-15 \% \quad D_{2}$ receptor occupancy is not straightforward, especially when prescribing haloperidol, since doses as low as $2.5 \mathrm{mg}$ of this drug result in a wide variation in striatal $\mathrm{D}_{2} / \mathrm{D}_{3}$ receptor occupancy (38-87\%).

Furthermore, individual responses to similar degrees of $\mathrm{D}_{2}$ receptor occupancy may vary, based on other as yet undefined pharmacogenetic characteristics and on the individual's underlying dopaminergic tone (Laruelle et al, 1996). It is pertinent to this point that hyperprolactinaemia occurred in $80 \%$ ( 4 out of 5 ) of the women and $24 \%$ ( 4 out of 17) of the men in the study by Kapur et al (2000a) despite similar levels of $\mathrm{D}_{2}$ receptor occupancy. Melkersson et al (2000) reported that in a group of patients receiving long-term typical antipsychotic therapy, the women developed symptomatic hyperprolactinaemia at half the chlorpromazine equivalent dose of that in men (approximately $250 \mathrm{mg}$ chlorpromazine equivalents).

\section{Dopamine transmission is abnormal in schizophrenia}

Post-mortem studies of $\mathrm{D}_{2}$ receptors in schizophrenia were crucial to the genesis of the dopamine hypothesis. Increased striatal $\mathrm{D}_{2}$ receptor density was reported by some authors (Lee \& Seeman, 1980; Mackay et al, 1982), but these findings were questioned on the basis that the data were obtained by studying antipsychotictreated patients. Classical antipsychotic therapy could, in itself, cause $\mathrm{D}_{2}$ receptor upregulation (Clow et al, 1980). Imaging studies using PET and SPET could control for this confound by studying never-treated people with schizophrenia. These studies did not, on the whole, support increased striatal $\mathrm{D}_{2}$ receptor density in schizophrenia (Farde et al, 1990; Martinot et al, 1990; Pilowsky et al, 1994), although the possibility that endogenous dopamine concentration was abnormal (Mackay et al, 1982; Reynolds, 1983) remained untested in vivo. Support for the central importance of dopaminergic antagonism in antipsychotic efficacy eventually came from $\left[{ }^{123} \mathrm{I}\right]-$ iodobenzamide SPET data suggesting that dopamine transmission was indeed disrupted in schizophrenia. Using dynamic challenge paradigms, Laruelle et al (1996) demonstrated an aberrant response in people with schizophrenia to a drug that elevated dopamine levels. Following administration of amphetamine, mean occupancy of striatal $\mathrm{D}_{2}$ receptors by amphetamine-stimulated endogenous dopamine release was approximately doubled in the patient group compared with the control group. This effect was more striking in the more acutely ill patients, although findings in many patients overlapped with those in controls. These data, replicated using a different PET technique (Breier et al, 1997), provided concrete proof of disturbed dopamine control, at least in some people with schizophrenia. Drawing on these and other data, Moore et al (1999) have thoughtfully argued that overactive phasic dopamine transmission in limbic regions (including the amygdala and nucleus accumbens) could account for misinterpretation of innocuous external stimuli (resulting in delusions) and improper filtering of perceptions (causing hallucinations). Blockade of $\mathrm{D}_{2}$ receptors in these regions would help control the positive symptoms of schizophrenia. In cortical (especially frontal and prefrontal cortical) regions, these authors propose that tonic dopamine transmission is relatively underactive, resulting in disrupted executive function, poverty of thought, speech and action, and low motivation. Antipsychotic occupancy of $D_{2}$ receptors in these regions would worsen these negative features. This attractively parsimonious model synthesises available data and meshes with the finding that atypical antipsychotic drugs (particularly clozapine and quetiapine) exhibit cortically selective $\mathrm{D}_{2}$ receptor occupancy (primarily temporal cortex, including amygdala and hippocampus) at clinically useful doses in vivo (Pilowsky et al, 1997; Lidow et al, 1998; Meltzer et al, 1999; Stephenson et al, 2000; Xiberas et al, 2001). This effect is not seen for standard 
doses of typical antipsychotic drugs (Bigliani et al, 1999). Importantly, drugs with modest affinity for $\mathrm{D}_{2}$ receptors exhibit this effect robustly across their whole dose range, whereas atypical drugs with higher affinity for the $\mathrm{D}_{2}$ receptor (e.g. risperidone) display dose-dependent limbic selectivity (Xiberas et al, 2001; Bressan et al, 2003; Fig. 1).

These data could not be replicated by Talvik et al (2001), and full in vivo PET or SPET confirmation awaits further study. Nevertheless, regionally selective dopaminergic action of atypical antipsychotic drugs is supported by both electrophysiological and animal studies (Lidow et al, 1998; Strange, 2001).

\section{How much $D_{2}$ blockade is too much?}

The advent of antipsychotic drugs with very low affinity for dopamine $\mathrm{D}_{2}$ receptors

(a)

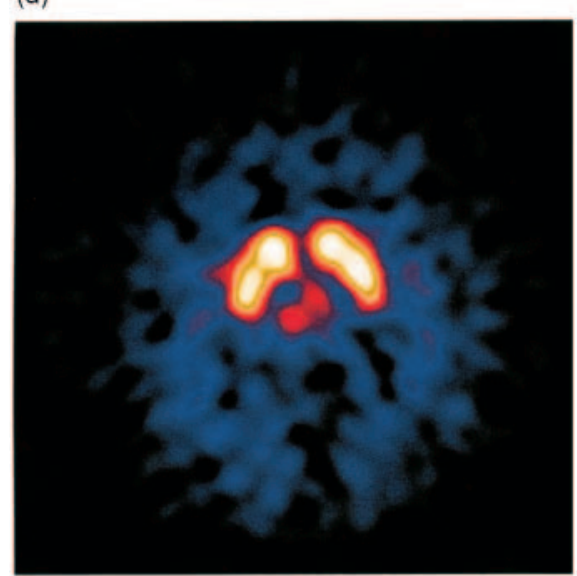

(b)

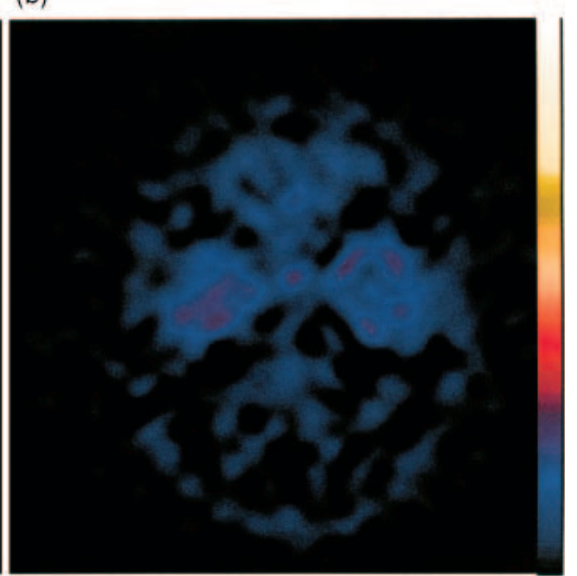

(c)

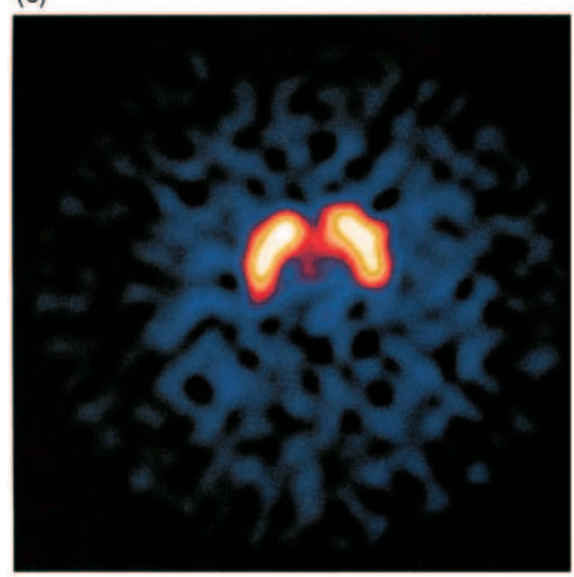

(d)

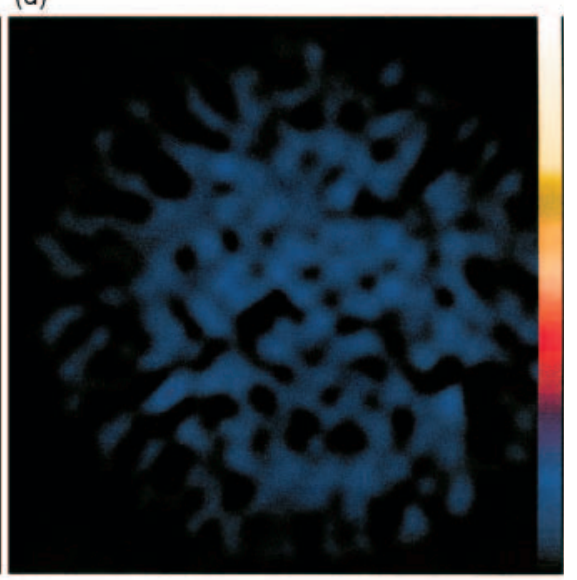

Fig. I Preferentially high occupancy of dopamine $D_{2} / D_{3}$ receptors in the thalamus and temporal cortex by risperidone in a patient treated with risperidone (dose $<4 \mathrm{mg}$ ) compared with a healthy volunteer (see Bressan et al, 2003). (a, b) Normal volunteer: (a) striatum and thalamus, (b) temporal cortex and cerebellum. (c, d) Patient treated with risperidone: (c) striatum and thalamus, (d) temporal cortex and cerebellum.

(most notably clozapine and quetiapine) begged the question whether $\mathrm{D}_{2}$ receptor blockade was invariably required for antipsychotic efficacy. Imaging studies using PET reveal that striatal $\mathrm{D}_{2}$ receptor occupancy by these drugs changes considerably over a $24 \mathrm{~h}$ period, even in steady state (Gefvert et al, 1998; Kapur et al, 2000b). Consideration of the $\mathrm{D}_{2}$ receptor affinity and occupancy data relating to typical and atypical antipsychotic drugs led Kapur \& Seeman (2001) to conclude that owing to low affinity for the $\mathrm{D}_{2}$ receptor (driven, as these authors see it, by fast dissociation 'off' the receptor) clozapine and quetiapine exhibit transiently high $\mathrm{D}_{2}$ receptor occupancy (not exceeding the threshold required to induce adverse movement or hormonal side-effects), which declines to very low levels over a $24 \mathrm{~h}$ period. This suggests that low-affinity drugs, with modest effects at $\mathrm{D}_{2}$ receptors, may antagonise the system in a manner that preserves physiologically

\section{TO AFFINITY. . . AND BEYOND! 'SMART' ANTIPSYCHOTIC DRUGS}

The above suggests that a reasonable goal for effective, less-toxic treatment of schizophrenia is the regionally sensitive stabilisation of dopamine function, and not the 'blunderbuss' dopaminergic paralysis induced by classical antipsychotic drugs. This selective targeting could come about by exploiting behaviour intrinsic to compounds with low $\mathrm{D}_{2}$ affinity, by designing compounds selective for dopamine receptor subtypes found at greater densities in limbic or cortical regions (for example $\mathrm{D}_{3}$ receptors), or by modulating dopamine release through action at alternative systems (novel candidates include serotonin, sigma and glutamate receptor sites). Such ideas are certainly relevant to current therapeutics and future drug development. Novel agents with specific action at presynaptic $\mathrm{D}_{3}$ autoreceptors controlling central dopamine release may offer more physiological modulation of dopamine than conventional antagonists (Reavill et al, 2000; Strange, 2001). It is apparent that as the neurochemical pathology of schizophrenia is not fully understood, and as many patients are only partially responsive or are insensitive to dopaminergic antagonism, many non-dopaminergic sites (especially those mediated by glutamate and serotonin) remain potent targets for future drug discovery. The availability of highand low-affinity $\mathrm{D}_{2} / \mathrm{D}_{3}$ receptor antagonist antipsychotic drugs offers clinicians much choice, and the above data provide a rational evidence base for prescribing, 
tailored as far as possible to individual patient responses.

\section{DECLARATION OF INTEREST}

H.M.J. is supported by an unrestricted charitable grant from Astrazeneca. L.S.P. is a UK Medical Research Council Senior Clinical Fellow and has received research grants from Astrazeneca, Novartis, Janssen and Sanofi-Synthelabo, and honoraria for lectures and consultancies to GlaxoSmith Kline, Astrazeneca, Novartis, Pfizer and Janssen.

\section{REFERENCES}

Baldessarini, R. J., Katz, B. \& Cotton, P. (1984) Dissimilar dosing with high and low potency neuroleptics. American Journal of Psychiatry, I4I, 748-752.

Bigliani, V., Mulligan, R. S., Acton, P. D., et al (1999) In vivo occupancy of striatal and temporal cortical $D_{2} / D_{3}$ dopamine receptors by typical antipsychotic drugs. $\left[{ }^{123} \mid\right]$ epidepride single photon emission tomography (SPET) study. British Journal of Psychiatry, I75, 231-238

Breier, A., Su, T. P., Saunders, R., et al (1997) Schizophrenia is associated with elevated amphetamine induced synaptic dopamine concentrations: evidence from a novel positron emission tomography method. Proceedings of the National Academy of Sciences of the USA, 94, 2569-2574.

Bressan, R. A., Erlandsson, K., Jones, H. M., et al (2003) Optimising limbic selective $D_{2} / D_{3}$ receptor occupancy by risperidone - a 1231 epidepride SPET study. Journal of Clinical Psychopharmacology, in press.

Clow, A., Theodoru, A., Jenner, P., et al (1980) Changes in rat striatal dopamine turnover and receptor activity during one year's neuroleptic administration. European Journal of Pharmacology, 63, 135-144.

Creese, I., Burt, D. R. \& Snyder, S. H. (1976) Dopamine receptor binding predicts clinical and pharmacological potencies of antischizophrenic drugs. Science, 192, 481-483.

Farde, L., Wiesel, F. A., Nordstrom, A. L., et al (1989) DI- and D2-Dopamine receptor occupancy during treatment with conventional and atypical neuroleptics. Psychopharmacology, 99, S28-S3I.

_ , _ , Stone-Elander, S., et al (1990) D2 dopamine receptors in neuroleptic-naive schizophrenic patients. A positron emission tomography study with [" $\mathrm{C}$ ] raclopride. Archives of General Psychiatry, 47, 213-219.

Gefvert, O., Bergstrom, M., Langstrom, B., et al (1998) Time course of central nervous dopamine-D2 and 5 - HT2 receptor blockade and plasma drug concentrations after discontinuation of quetiapine (Seroquel) in patients with schizophrenia. Psychopharmacology (Berlin), I35, I19-126.

Johnstone, E. C., Crow, T. J., Frith, C. D., et al (1978) Mechanism of the antipsychotic effect in the treatment of acute schizophrenia. Lancet, i, 848-851.

Jones, H., Travis, M. J., Mulligan, R. S., et al (200I) In vivo $5 \mathrm{HT} 2$ a receptor blockade by quetiapine. An R9II50 single photon emission tomography study. Psychopharmacology (Berlin), 157, 60-66.

H. M. JONES, MRCPsych, L. S. PILOWSKY, MRCPsych, Institute of Psychiatry, London, UK

Correspondence: Dr L. S. Pilowsky, Institute of Psychiatry, De Crespigny Park, Denmark Hill, London SE5 8AF,UK. Tel: 0207848 0531 ; e-mail: I.Pilowsky@iop.kcl.ac.uk

(First received 3 December 200I, final revision I5 April 2002, accepted I5 April 2002)

Kapur, S. \& Seeman, P. (200I) Does fast dissociation from the dopamine D2 receptor explain the action of atypical antipsychotics? A new hypothesis. American Journal of Psychiatry, I58, 360-369.

_ , Zipursky, R. \& Remington, G. (1999) Clinical and theoretical implications of 5-HT2 and D2 receptor occupancy of clozapine, risperidone, and olanzapine in schizophrenia. American Journal of Psychiatry, I56, 286-293.

_ , _ , Jones, C., et al (2000a) Relationship between dopamine $\mathrm{D}(2)$ occupancy, clinical response, and side effects: a double-blind PET study of first-episode schizophrenia. American Journal of Psychiatry, 157, 514-520.

_ _ , et al (2000b) A positron emission tomography study of quetiapine in schizophrenia. Archives of General Psychiatry, 57, 553-559.

Kerwin, R.W. (1994) The new atypical antipsychotics. A lack of extrapyramidal side-effects and new routes in schizophrenia research. British Journal of Psychiatry, 164, $|4|-148$

Konradi, C. \& Heckers, S. (200I) Antipsychotic drugs and neuroplasticity: insights into the treatment and neurobiology of schizophrenia. Biological Psychiatry, 50 729-742.

Laruelle, M., Abi-Dargham, A., Van-Dyck, C. H., et al (1996) Single photon emission computerized tomography imaging of amphetamine-induced dopamine release in drug-free schizophrenic subjects. Proceedings of the National Academy of Sciences of the USA, 93, 9235-9240.

Lee, T. \& Seeman, P. (1980) Elevation of brain neuroleptic/dopamine receptors in schizophrenia. American Journal of Psychiatry, 137, 191-197.

Lidow, M. S., Williams, G.V. \& Goldman-Rakic, P. S. (1998) The cerebral cortex: a case for a common site of action of antipsychotics. Trends in Pharmacological Sciences, 19, 136-140

Mackay, A. V., Iversen, L. L., Rossor, M., et al (1982) Increased brain dopamine and dopamine receptors in schizophrenia. Archives of General Psychiatry, 39, 991-997.

Martinot, J. L., Peron-Magnan, P., Huret, J. D., et al (1990) Striatal D2 dopaminergic receptors assessed with positron emission tomography and ${ }^{76} \mathrm{Br}$ bromospiperone in untreated schizophrenic patients. American Journal of Psychiatry, 147, 44-50.

Melkersson, K. I., Hulting, A. L., Rane, A. J. (2000)

Dose requirement and prolactin elevation of antipsychotics in male and female patients with schizophrenia or related psychoses. British Journal of Clinical Pharmacology, 51, 317-324.

Meltzer, H. Y., Matsubara, S. \& Lee, J. C. (1989) The ratios of serotonin and dopamine2 affinities differentiate atypical and typical antipsychotic drugs. Psychopharmacology Bulletin, 25, 390-397.

_ , Park, S. \& Kessler, R. (1999) Cognition, schizophrenia and the atypical antipsychotic drugs. Proceedings of the National Academy of Sciences of the USA, 96, $13591-13593$.
Moore, H., West, A. R. \& Grace, A. A. (1999) The regulation of forebrain dopamine transmission: relevance to the pathophysiology and psychopathology of schizophrenia. Biological Psychiatry, 46, 40-55.

Nordstrom, A. L., Farde, L. \& Halldin, C. (1993a) High $5 \mathrm{HT} 2$ receptor occupancy in clozapine treated patients demonstrated by PET. Psychopharmacology, II0, 365-367.

_ , _ , Weisel, F. A., et al (1993b) Central D2 dopamine receptor occupancy in relation to antipsychotic drug effects: a double blind PET study of schizophrenic patients. Biological Psychiatry, 33, 227-235.

Nyberg, S., Farde, L., Eriksson, L., et al (1993) $5 \mathrm{HT} 2$ and D2 dopamine receptor occupancy by risperidone in the living human brain. Psychopharmacology, II0, 265-272.

Peroutka, S. J. \& Snyder, S. H. (1980) Relationship of neuroleptic drug effects at brain dopamine, serotonin, alpha-adrenergic and histaminergic receptors to clinical potency. American Journal of Psychiatry, 137, 1518-1522.

Pilowsky, L. S., Costa, D. C., EII, P. J., et al (1992)

Clozapine, single photon emission tomography and the D2 dopamine receptor blockade hypothesis of schizophrenia. Lancet, 340, 199-202.

_, _ , _ , et al (1993) Antipsychotic medication, D2 dopamine receptor blockade and clinical response - a 123I IBZM SPET (single photon emission tomography) study. Psychological Medicine, 23, 791-799.

$\ldots$, _ , _ , et al (1994) $D_{2}$ dopamine receptor binding in the basal ganglia of antipsychotic free schizophrenic patients. An ${ }^{123}$ I-IBZM single photon emission computerised tomography study. British Journal of Psychiatry, 164, 16-26.

_, Mulligan, R. S., Acton, P. D., et al (1997) Limbic selectivity of clozapine. Lancet, 350, 490-49I.

Reavill, C., Taylor, S. G., Wood, M. D., et al (2000) Pharmacological actions of a novel high-affinity, and selective human dopamine D2 receptor antagonist, SB-2770II-A. Journal of Pharmacology and Experimental Therapeutics, 294, II54-1165.

Reynolds, G. P. (1983) Increased concentrations and lateral asymmetry of amygdala dopamine in schizophrenia. Nature, 304, 527-528.

Seeman, P., Lee, T., Chau-Wong, M., et al (1976) Antipsychotic drug doses and neuroleptic/dopamine receptors. Nature, 261, 717-718.

Stephenson, C. M. E., Bigliani, V., Jones, H. M., et al (2000) Striatal and extra-striatal $D_{2} / D_{3}$ receptor occupancy by quetiapine in vivo. [23/]-epidepride single photon emission tomography (SPET) study. British Journal of Psychiatry, 177, 408-4I5.

Strange, P. G. (200I) Antipsychotic drugs: importance of dopamine receptors for mechanisms of therapeutic actions and side effects. Pharmacological Reviews, 53 , $119-133$

Talvik, M., Nordstrom, A. L., Nyberg, S., et al (200I) No support for regional selectivity in clozapine treated patients: a PET study with ["C] raclopride and 
["C] FLB 457. American Journal of Psychiatry, I58, 926-930

Taylor, P. \& Insel, P. A. (1990) The molecular basis of pharmacologic selectivity. In Principles of Drug Action The Basis of Pharmacology (eds W. B. Pratt \& P. Taylor), pp. I-102. London: Churchill Livingstone.

Thompson, C. (1994) The use of high-dose antipsychotic medication. British Journal of Psychiatry, 164, 448-458.
Travis, M. J., Busatto, G. F., Pilowsky, L. S., et al (1998) 5 HT2a receptor blockade in schizophrenic patients treated with risperidone or clozapine, a |23I-5-I-R-9||50 single photon emission tomography (SPET) study. British Journal of Psychiatry, I73, 236-24I.

Van Putten, T. \& Marder, S. (1986) Low dose treatment strategies. Journal of Clinical Psychiatry, $\mathbf{4 7}$ (suppl. 12), I-6.
Wolkin, A., Barouche, F., Wolf, A. P., et al (1989) Dopamine blockade and clinical response: evidence for two biological subgroups of schizophrenia. American Journal of Psychiatry, 146, 905-908.

Xiberas, X., Martinot, J. L., Mallet, L., et al (200I) Extrastriatal and striatal $\mathrm{D}_{2}$ dopamine receptor blockade with haloperidol or new antipsychotic drugs in patients with schizophrenia. British Journal of Psychiatry, 179, 503-508. 